\title{
A escrita como cena substitutiva da Pólis: memória, silêncio e testemunho em Salinas Fortes GILMÁRIO GUERREIRO DA COSTA I
}

Para Carla Milani Damião

\section{Cenas introdutórias}

\begin{abstract}
Através do confuso esplendor através da noite de pedra, deixa-me enfiar a mão e deixa que em mim palpite, como ave mil anos prisioneira o velho coração do esquecido! (Neruda, 1996, p.38).
\end{abstract}

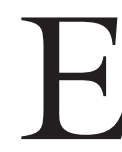

M ALGUMAS narrativas autobiográficas não é fácil discernir o limite entre a necessidade subjetiva da denúncia de determinada injustiça e o esforço por encenar na escrita o espaço público do testemunho. Os dois níveis se sobrepõem especialmente nas memórias de eventos históricos traumáticos. Nesses períodos os espaços de intervenção política fecham-se e se submetem à vigilância cotidiana, as relações sociais se fragmentam, a amizade se vê paulatinamente tornar-se paranoia e desconfiança. A busca de resistência a essas estruturas assume diversas frentes, da expressão cultural até a via armada. Também encontra na escrita espécie de cena substitutiva da pólis momentaneamente tomada de assalto pela repressão sistemática e pelas diversas formas de violência estatal. É exemplar a esse respeito o livro Retrato calado (Fortes, 2012) - publicado postumamente em 1988 -, de Luiz Roberto Salinas Fortes (1937-1987).

Sobressai nessa obra a articulação de elementos autobiográficos, busca e desencontro de si e testemunho das prisões que enfrentou por motivos políticos durante a ditadura militar no Brasil. A tortura física e psicológica que sofreu projeta as suas sombras em todas as páginas, o que repercute no espaço de uma escrita tecida no limite da impossibilidade da expressão confessional completa e bem-sucedida, seja no plano autobiográfico, seja no plano político. As três partes em que se divide essa narrativa parecem conceder a forma apropriada a semelhante desconfiança. Na primeira, que se chama "Cena primitiva", o autor busca narrar as torturas de que foi vítima, ao mesmo tempo em que reflete acerca das condições de possibilidade desse tipo de escrita. O silêncio é uma figura impor- 
tante aqui. Segue-se "Suores noturnos", espécie de diário íntimo incompleto. Encerra-se com "Repetição", conduzindo adiante as reflexões sobre memória e testemunho. Em tudo isso predomina uma linguagem lúcida e o olhar atento às contradições políticas da época e à incomensurabilidade da busca de si mesmo.

\section{Silêncios ou como narrar o trauma: sinceridade e esquecimento}

Uma parte da nossa existência está nas almas de quem se aproxima de nós; por isso, não é humana a experiência de quem viveu dias nos quais o homem foi apenas uma coisa ante os olhos de outro homem.

(Levi, 1988, p.173)

$\mathrm{Na}$ abertura do livro, dispõe-se em uma frase concisa a imagem física de um agente da repressão, na qual se vai discernindo o caráter de parcela considerável do quadro institucional dos serviços de segurança e investigação do país: "O magricela sorri dentro do elevador. Sorri o magricela, irônico, dentro do elevador" (Fortes, 2012, p.21). Junto ia o autor, que levava consigo um embrulho, a pedido dos policiais. Nada sabia do seu conteúdo. Descobriria instantes depois que se tratava de um instrumento de tortura: "envolto em jornais, para disfarçar, nada mais, nada menos do que o aparelho de choque a cujas iluminações, dali a pouco, paudiararizado, viria eu a ser submetido graciosamente" (ibidem, p.22). O grupo ri despudoradamente da cena: "E eu, atônito, catatônico, arremessado de repente em meio ao inferno, transferido de súbito para esta dimensão nova onde tudo se passa velozmente, embora dure uma eternidade e embora se propague pela eternidade afora" (ibidem, p.22). Semelhante evento mudaria definitivamente a sua vida. Todo o processo é tão insólito que parece assinar os limites da mimese.

Essa parte inicial do livro chama-se "Cena primitiva". Parece aludir à reflexão freudiana sobre o trauma, especialmente no texto "História de uma neurose infantil ('O homem dos lobos')", o qual aduz o tratamento de um nobre russo diagnosticado com transtorno maníaco-depressivo. Na quarta seção do trabalho, que se intitula "O sonho e a cena primária", ${ }^{1}$ Freud $(2010$, p.28s) relata o sonho do paciente: encontrava-se em seu quarto, em uma noite de inverno, quando a janela se abriu e viu, do outro lado, sete lobos brancos que o observavam. Ele gritou, com medo de ser comido por esses animais, e acordou imediatamente. A interpretação que Freud propôs a esse evento liga-se a uma complexa rede de relacionamentos familiares na infância e a um momento em que surpreende os pais durante o ato sexual. A questão mais propriamente ligada ao texto de Salinas Fortes é a de como narrar uma situação traumática, tendo perante si não a figura do analista, mas os silêncios e limites da memória e da linguagem, bem como a resistência à autocomplacência, de modo que pudesse incluir tanto quanto possível as dores e desalento de toda uma geração.

João Quartim de Moraes (1988, p.150) lança luz considerável sobre o modo como Salinas Fortes enfrentou essa situação. Inicialmente enfatiza a desi- 
gualdade de forças entre torturado e torturador: "Em nenhum outro combate a desigualdade de forças é tão completa quanto no do torturado contra seus torturadores". É um encontro desigual não apenas pelas forças envolvidas, mas também pela distância entre as hesitações e dúvidas dos prisioneiros e as certezas inarredáveis dos torturadores: "Face às hesitações e dilaceramentos do prisioneiro, os algozes exibiam suas sórdidas mas sólidas certezas" (ibidem). O esforço do prisioneiro não se concentrava na exibição de coragem sobre-humana; antes, impunha-se a necessidade de manter a lucidez e a fidelidade a si e aos companheiros. As poucas escolhas dadas assumem um teor trágico que não escapa à análise sensível de Quartim de Moraes: entre a morte física e a vergonha moral, esse outro tipo de morte, porém mais prolongada: "a tortura aparece em sua sinistra crueza como máquina de triturar corpos e consciências, ambos, se necessário, e as consciências, se não for necessário triturar os corpos" (ibidem, p.152).

A Salinas Fortes, especialista em Rousseau, depara o desafio de seguir o caminho de seu mestre: o da busca da sinceridade. A formulação clássica a esse respeito encontra-se em As confissões (1764-1770): "Mostrei-me tal qual fui: desprezível e vil, quando o hei sido; bom, generoso, sublime, quando o hei sido; revelei o meu íntimo tal qual como tu próprio o viste. [...] Que, junto ao teu trono, cada um deles abra, por sua vez, o coração com a mesma sinceridade" (Rousseau, 1964, p.15). Essa confiança seria matizada adiante durante a escrita de Os devaneios do caminhante solitário (1776-1778). Aqui o desejo de sinceridade e exposição das suas próprias contradições e ações ignominiosas perde a força perante a purificação a que as adversidades submeteram o autor. Tais dificuldades ganham relevo especialmente na "Quarta caminhada", com a sua meditação sobre a mentira. Coloca dúvidas sobre a exequibilidade de máxima "conhece-te a ti mesmo". Inicialmente, faz referência a uma mentira que disse em sua juventude, cujas consequências mostraram-se deletérias para uma jovem empregada, chamada Marion. Disso adviria seu alegado horror à mentira. Em passagem marcada por notável discernimento, o autor desvela os móveis da sua extremada defesa da verdade em suas Confissões, cujo efeito foi o de ludibriar-se a si mesmo com as excessivas reprimendas às quais se submeteu. No afã de resistir à mentira, haveria de conformar-se a outras formas de engano; por amor à verdade, serviu-se de formas inauditas de dissimulação. A sinceridade consigo mesmo pertenceria à dimensão ética, constituindo-se em uma forma de justiça, cuja apreciação mais rigorosa exige a distinção entre veracidade e fidelidade. Repousará sobre a primeira a escolha de Rousseau, de que decorrem consequências pedagógicas em sentido amplo: "A preocupação com a sinceridade significava educar-se moralmente, na condição do dever-ser. Se nem sempre é possível mostrar-se como realmente se é, aquele que assim procede, poderá tornar-se, talvez, o que deveria ser" (Damião, 2015, p.18). ${ }^{2}$

Tais seriam as exigências da sinceridade como veracidade. O próximo passo implica investigar que tipo de expectativa legítima se pode atender no 
relato do passado. Jeanne Marie Gagnebin (2006, p.39) formula a esse respeito esta hipótese: "Entendo com isso que a verdade do passado remete mais a uma ética da ação presente que a uma problemática da adequação (pretensamente científica) entre 'palavras' e 'fatos'. Lembra que Walter Benjamin sustentou a impossibilidade de uma descrição histórica do passado tal como ele realmente foi. Tal se deve a dificuldades epistemológicas e exigências ético-políticas. $\mathrm{O}$ problema não se vincularia propriamente ao nível de sinceridade do historiador historicista, mas sim às contradições da sua estrutura positivista que o obrigam a renunciar à própria historicidade do seu discurso (Gagnebin, 2006). Na história contemporânea emergiram discussões historiográficas atentas a esses problemas. Despontaram estudos que sublinharam os componentes ficcionais na escrita da histórica e os seus momentos inevitáveis de esquecimento. Não obstante, tais considerações enfrentariam dois riscos não menos problemáticos do que os presentes nas narrativas historicistas: ficcionalização extremada, que não mais discerne as suas bordas, por um lado, e relativismo extremo, por outro: "relativismo apático, já que todas as versões se equivalem" (Gagnebin, 2006, p.42). No esforço por distanciar-se do que chama de "relativismo complacente", a autora apresenta e discute alternativas ao conceito de verdade como correspondência e verificação. Detém-se especialmente no conceito de "referência não descritiva do mundo", com o qual Paul Ricoeur se empenhou por divisar algumas sendas para a devida compreensão da verdade da poesia (ibidem, p.42-3).

Outro problema se articula com a expectativa de sinceridade e o caráter específico da narrativa história: o entendimento de que memória e esquecimento implicam-se mutuamente. $\mathrm{O}$ esquecimento não é vazio total ou não ser: trata-se de um ser adiado - o esquecimento "fala" da memória, assim como a memória do esquecimento. Há certo liame metonímico entre ambos, que se descerra pela figura da temporalidade, lançando-se um no outro, sem solução definitiva. Uma contribuição especialmente relevante a esse problema encontra-se no livro Lete, de Harald Weinrich (2001). O título alude à deusa do esquecimento e ao rio, na mitologia grega. A deusa pertence à linhagem da Noite, cuja mãe é a discórdia. O rio, por seu turno, figura na imagem líquida o movimento com que se atenua e se desfaz a rigidez dos elementos da realidade e da vigília: "Há um profundo sentido no simbolismo dessas águas mágicas. Em seu macio fluir desfazem-se os contornos duros da lembrança da realidade, e assim são liquidados" (Weinrich, 2001, p.24). O autor examina cuidadosamente os diversos recursos de mnemotécnica até o início da época moderna, quando a invenção da imprensa vai paulatinamente tornando os livros mais acessíveis. O que durante séculos era o adversário a vencer, o esquecimento, configuraria um peso cada vez maior a carregar-se, o do excesso de informações. Desse modo, não era mais a questão de prover meios apropriados à memorização o que importava, e sim a dos critérios para o que seria possível e recomendável esquecer. As implicações pedagógicas dessa mudança foram consideráveis, já presentes em Montaigne, para quem 
um ensino orientado para guardar dados e eventos se lhe afiguravam danosos à formação de crianças e jovens. Em termos políticos, o fim das guerras até o século XVIII e XIX - tal como o Tratado de Westfália de 1648, no contexto do fim da Guerra dos Trinta Anos (1618-1648), e a promessa de Luís XVIII em 1814 - não raro se acompanhavam do imperativo da anistia e do esquecimento. Semelhante dispositivo se tornaria problemático no século XX, quando ganha relevo a dúvida se os crimes de guerra "cada vez mais pavorosos a elas ligados" poderiam "ser apagados da memória da humanidade por uma ordem de esquecer" (Weinrich, 2001, p.238). Nesse contexto, emerge o importante tema do dever da memória perante as gerações futuras.

Preocupações similares compõem a narrativa de Salinas Fortes. Buscou prestar testemunho do trauma histórico que vivenciou, sem perder de vista a unicidade das suas próprias dores. Haveria de decidir-se pelo modo de conceder a forma mais apropriada ao relato, e opta por um tipo de distanciamento que permite ampliar o testemunho e também evitar expressão demasiado subjetiva, com que poderia avizinhar-se de uma indesejada autocomplacência.

\section{A difícil arte do distanciamento}

[...] me pergunto se o que estou fazendo agora não é culpável aquiescência à paixão terrestre da rememoração, tola tentativa de escapar ao fluxo do tempo e à morte.

(Eco, 1986, p.325)

A sobriedade e a serenidade distintivas dessa obra contribuem para a busca de um difícil distanciamento, passível de manifestar as dificuldades e dores que enfrentou, sem o recurso a um mero transbordamento que poderia concorrer para o desgaste rápido da expressão. Além disso, a via seguida permite tornar a sua escrita em cena substitutiva da pólis que se fechou aos esforços de debate e participação dos seus cidadãos: "O tempo todo ele parece estar no centro sem chamar atenção, simultaneamente sujeito e objeto, graças à maestria da escrita e à invariável dignidade intelectual" (Candido, 2012, p.124). Deve-se em grande medida à integridade do narrador semelhante discrição e lucidez: "No meio da perplexidade, o drama do ser mistura-se aos dramas do mundo e o narrador parece alguém que soube, através da palavra, construir-se e ao mesmo tempo denunciar, com a inteireza dos que não enfeitam nem deformam" (ibidem, p.125). $\mathrm{O}$ sujeito de enunciação articula a proximidade dolorosa do testemunho e o distanciamento passível de conceder certa nitidez à cena do trauma e da crise: "Oscilação entre um eu colado e um ele que produz a distância, que expressa literariamente a quase que impossibilidade de reconhecimento da Cena, do seu absurdo" (Cardoso, 1998, p.12-13). Essas escolhas estilísticas predominantes na obra contribuem igualmente a que os leitores "vejam" melhor, como se pode avaliar, por exemplo, nesta passagem:

$\mathrm{Nu}$, completamente nu. Obrigam o paciente a sentar no chão. Amarram-me as mãos, que protegem com uma cobertura de pano, uma contra a outra. Forçam-no a manter os joelhos unidos, dobrados contra o peito 
e envolvidos pelos braços amarrados. No vão entre os braços e o joelho enfiam uma barra de ferro e penduram-na - penduram-me - em dois cavaletes. Rápidos, eficientes, bem treinados. (Fortes, 2012, p.23)

Essa atenção aos procedimentos sublinha uma racionalidade afim ao desvario. A cena surreal emerge da estrita normalidade do cotidiano. Um dos responsáveis pelos processos que Salinas Fortes enfrentou era o delegado Zildo, que explicou com profissionalismo exemplar os pormenores das sessões de tortura. Nota o quanto o aprimoramento do instrumento representa uma conquista social: "A grande conquista, como é óbvio, destina-se a anulações dos vestígios da tormentosa passagem pelo famigerado pauzinho" (Fortes, 2012, p.23). Em todo esse expediente predomina o recurso à linguagem técnica, afeito à coerência entre forma e fundo no exercício da sua atividade. Recorrendo a uma frase admirável, o autor apresenta o trauma e temporalidade perante o sadismo e alucinação na administração racional do poder vigente: "reconfortante revolta que não mais me abandonaria" (ibidem, p.24). Cuida em compor um enredo a que não falta o rigor e a objetividade possíveis: "Deixemos, porém, que os fatos se contem, os sucessos se sucedam e a história se refaça" (ibidem, p.25). A certa altura escreve em parágrafo com um único período uma digressão na qual se permite um questionamento radical e espécie de exorcismo: ${ }^{3}$ há a perspectiva de certo entendimento do processo, ainda que não ofereça redenção, sendo possível que mesmo expectativas tão modestas não sejam atendidas pelo relato.

Nas camadas intertextuais dessa narrativa, suscita interesse a referência a Platão, em especial a menção ao sofista Trasímaco, conforme descrito no primeiro livro da República. Sublinha o modo como ele corta a palavra de Sócrates. Torna-se a figura da violência e da impossibilidade do diálogo, passível de reunir em sua caracterização a essência dos gestos dos interrogadores que tomaram de assalto salas de interrogatório político à época no país: "Como se, de repente, a própria realidade, pegando-me pela palavra, se pusesse a ilustrar e comentar as peripécias abstratas do discurso filosófico, corporificando as teses de Trasímaco" (Fortes, 2012, p.27-8). Correlato a isso, seguirá a negação prática da justiça, ainda que se estribe na defesa cínica dos valores mais altos da nação: "comporta-se como se toda comunicação através da linguagem não passasse de simples exteriorização do confronto entre vontades de potências adversas" (ibidem, p.28). É nessa direção que se desdobram e se revelam as ações dos herdeiros de Trasímaco. Tem feição consideravelmente irônica um conhecimento que revelou e iludiu - ou talvez mais precisamente iludiu ao revelar. Nessa cena primitiva do trauma os aspectos escatológicos da descrição se subtraem à representação simbólica efetiva.

Como bom narrador, Salinas Fortes descreve com clareza visual a gradação do movimento rumo à cela: "Escada abaixo. $\mathrm{O}$ andar térreo. $\mathrm{O}$ pátio, de novo. As celas. $\mathrm{O} \mathrm{Xl}$, as portas da grade que rangem e se fecham, deixando-me na companhia dos outros três" (ibidem, p.30). O cruzamento temporal e a 
irônica inversão dos signos são recursos com os quais oferece perspectivas múltiplas da sua experiência, bem como permitem visada crítica no espetáculo de nacionalismo e violência que as autoridades patrocinavam sem escrúpulos. Nessa época, o inferno só pode mesmo tornar-se em paraíso, e este, em seu oposto. A digressão a que nos referimos começou à página 26. Informa que já estivera na Oban, na rua Tutoia, no bairro do Paraíso. Foi interrogado durante dez dias, especialmente por sua vinculação com a ex-esposa, Veridiana. O corte temporal é bem realizado e parece conceder a pausa característica de uma experiência traumática. A referência ao milagre econômico propalado pela ditadura não poderia ser menos sarcástica: "A vida cotidiana nos cárceres do milagre" (ibidem, p.35). Em semelhante quadro, uma reflexão filosófica sobre a liberdade depara com objetos inusitados. Um deles, a sua associação aos odores do cotidiano na prisão. Nesse espaço e tempo em que se devassam todos os segredos, a intimidade torna-se um luxo desnecessário. A ideia mesma de resistência, que significaria o enfrentamento de uma situação externa inaceitável, apresenta dificuldades quando os limites entre vida pública e privada se desvanecem: "Perder a liberdade é também ser privado de qualquer controle sobre os odores próprios e alheios, dos companheiros amontoados nos aromáticos aposentos" (ibidem, p.35).

A narrativa põe a nu esses homens dos serviços de investigação que viram legitimados seu sadismo sob o novo regime político. Para muitos deles, as palavras de ordem ideológicas concernentes aos pretensos valores elevados da nação eram apenas a senha oportuna para executarem livremente ações que teriam mais dificuldade de levar a cabo em outras circunstâncias. Com respeito a esse discurso ideológico vigente, Salinas Fortes parece investigar duas dimensões prevalentes: a primeira, daqueles que não sabiam o que faziam, segundo a formulação marxiana; o segundo, daqueles que sabiam, mas continuavam a fazer, em uma cifra cínica. ${ }^{4}$ No primeiro caso, desponta a alienação; no segundo, o sadismo. Em qualquer das situações, insinua-se o entrelaçamento entre política e patologia. Forja-se nesse ambiente uma nova (in)sensibilidade, quando o valor positivo da resiliência torna-se em capitulação incontornável. Não resta senão o desalento de quem deve conformar-se: "Com os berros da moça que vai sendo torturada em alguma sala das proximidades. Com o mau cheiro permanente. Com a imobilidade. Com o chão duro em que se deita nossa cabeça na expectativa do sonho" (ibidem, p.39).

Da experiência do trauma vivido resulta a perda de inocência: a inocência política, em um primeiro plano, e a inocência perante o conjunto da vida, em nível mais amplo. Dessas rupturas surge um quadro de desengano, cuja aprendizagem está longe de ser evidente. Tudo isso conduz a um aprendizado inútil. Mas se é assim, por que então trabalhar semelhante narração? Provavelmente, por um dever de rememoração: "A passagem pelos subterrâneos do regime, o contato com o avesso do milagre eram, nestas condições, a ocasião para um aprendizado tão importante quanto inútil, pelo menos durante muitos anos” 
(ibidem, p.41). A profundidade do trauma sofrido era tamanha que por vezes fazia vacilar as fronteiras entre ficção e realidade. É nesse contexto que se lê uma passagem difícil, que articula os paradoxos da dor, sofrimento e desrealização. Suas hesitações não se orientam pela dúvida do sábio, mas pela impotência na simbolização do mal. O modo de escapar a tais armadilhas seria mediante o relato cuidadoso, fenomenológico. Porém, não parece tratar-se da tentativa de retorno às coisas mesmas. Mais propriamente, o esforço do autor é o de fazer emergir um mundo histórico e de objetos, não se limitando, nesse sentido, à expressão das emoções do sujeito, embora o espaço a elas concedido esteja garantido logo nas primeiras páginas. Para que ecoe mais amplamente o grito que as palavras mal conseguem traduzir, importa ampliar o foco da percepção de si e dos leitores. Nesse âmbito, tece considerações sobre a escrita e a narração, que revelam um escritor consciente do desafio que tem diante de si: "Contra a ficção do Gênio Maligno ${ }^{5}$ oficial se impõe o minucioso relato histórico e é da boa mira neste alvo que depende o rigor do discurso" (ibidem, p.42). Um pouco adiante, faz esta indagação: "Mas como evocar com exatidão o primeiro ato do pesadelo que a consciência tem dificuldade em reviver e se esforça por manter, recalcado, fora do seu âmbito?" (ibidem, p.42). É uma pergunta crucial, que pode servir de mote ao projeto e às dificuldades do livro. O verbo utilizado, "evocar", fornece os indícios do esforço do autor - não apenas se convocam as emoções, mas também a emergência do mundo onde tais processos se tornaram possíveis. Nessa escrita em espiral, como se verá adiante, reencontram-se o testemunho pessoal e o silêncio da cidade.

Em sua urdidura temporal, essa narrativa não segue a ordem cronológica dos acontecimentos, o que lhe permite montar com recursos diversos a expressão mais adequada ao trauma. As frases iniciais do livro referem-se à segunda prisão, quando o submeteram à tortura física. Mas logo nos apresenta os eventos que o levaram ao primeiro encarceramento. Passadas algumas páginas, surpreende o leitor com o retorno à cena inicial da tortura. É, como ele mesmo o define, uma narrativa em espiral: "Tudo se precipita e ei-nos enrolados em espirais a nos enrolarem espiraladamente, eis-nos confundidos em sendas várias [...] $\mathrm{Nu}$, pendurado, os choques. Como retratar a cena que retorna?" (ibidem, p.53). Nessa última pergunta encontram-se as dúvidas acerca dos limites do dizível em vivências traumáticas, a que o livro busca conceder a forma apropriada. Em uma passagem de A teoria estética, de Theodor Adorno (1982, p.30), há uma preocupação semelhante: "O sofrimento, reduzido ao seu conceito, permanece mudo e sem consequências". Não se trata de negar legitimidade a essa sorte de conhecimento, mas de sublinhar os seus limites, de modo que não se comprometa ironicamente com a própria violência que imaginava denunciar.

$\mathrm{O}$ uso do discurso indireto em determinadas passagens concede forma ao distanciamento distintivo da obra, como nesse momento em que incorpora o discurso dos agentes do sistema repressivo da ditadura: "Como queriam 
que agíssemos? Violência gera violência, meus senhores. $\mathrm{O}$ absurdo não teria sido, ao contrário, querer manter as regras de civilidade em meio a uma guerra suja e contra um inimigo implacável, a tudo disposto?" (Fortes, 2012, p.61). Qual a réplica para semelhante disparate, para esse maquiavelismo tropical? Possivelmente, o silêncio. Não por inexistirem argumentos, mas talvez porque essa mostra generosa de cinismo não merecia ser contraposta por discurso mais alto: "Não seria o caso de evocarmos o torrencial discurso sociológico-moral, ético-jurídico, recheado de lutas de classe e marxismos a perder o fôlego [...]? Não, poupemos o ouvinte, contenhamos a indignação e calemo-nos. Não é melhor assim?" (ibidem, p.61). A pergunta está longe de ser meramente retórica, pois não se a responde satisfatoriamente com uma afirmativa pressuposta ou uma negativa insubmissa; antes, a sua própria formulação já é a figura de um escândalo. No espaço fugidio da memória, a busca de si e da compreensão da sua época movem as páginas desse livro de linguagem cristalina e elegante, mas difícil.

\section{Fragmentos de um diário adiado}

Cada um está só no coração da terra traspassado por um raio de sol: e de repente é noite.

(Quasimodo, 1999, p.19)

A segunda seção do livro estrutura-se em uma forma-diário, que se circunscreve a dez dias da juventude do autor. Oferece um contraste incômodo, dadas as suas expectativas e indagações, com a passagem sombria que se leu na seção anterior. Desse entrechoque não se extrai exatamente uma síntese. $\mathrm{Na}$ armação dialética da narrativa a tese já se inicia marcada por uma negatividade insuperável.

Quartim de Moraes (1988, p.153) apresenta uma hipótese para a inserção dessa parte. Parece-lhe ser o meio de explorar camadas mais profundas da consciência, exame necessário ao devido encaminhamento narrativo da experiência traumática: "Como na ancestral técnica narrativa d'As Mil e uma noites, em que dentro de um conto surge outro conto, a reativação das angústias do cárcere conduz o narrador a revisitar ansiedades depositadas em camadas mais profundas da memória". A dor que os algozes infligiram a Salinas Fortes o reconduziria ao exame de pesadelos na adolescência. A referência às Mil e uma noites é sugestiva, mas talvez se deva sublinhar o corte nas linhas que movimentam esses “contos” na narrativa de Salinas Fortes. Não é uma história que entretém e faz esquecer o tempo, mas a memória que luta contra o esquecimento - ou que não pode ou não deve esquecer.

Antonio Candido (2012, p.124) serve-se de outra hipótese, um pouco diferente, embora não contradiga necessariamente a anterior: "Forçando a nota, pode-se dizer que as páginas confessionais, postas no meio, simbolizam pela simples posição a pessoa apertada entre duas conjunturas repressoras". A figura do estreitamento seria plausível especialmente quando se sublinham as situações 
de angústia presentes no livro. A afirmação de se tratar de texto confessional, no entanto, oferece dificuldades. Salinas não está confessando alguma injustiça em busca de perdão. Foi antes a vítima dos processos que narra. O diário, nesse sentido, por ser uma escrita supostamente espontânea e mais próxima da experiência, difere consideravelmente da confissão. Essa caracteriza-se por ser pensada, premeditada diante da autoridade do destinatário.

Pode-se ainda sugerir a possibilidade de instruir-se um contraste entre as expectativas do jovem que chegava à cidade para iniciar os seus estudos superiores e a violência que transtornaria a sua vida alguns anos adiante. Nesse sentido, as duas hipóteses examinadas se articulariam em um quadro hermenêutico marcado pela impossibilidade da harmonia entre sujeito e sociedade, em mais uma peça dessa escrita como cena substitutiva da pólis.

A primeira entrada do diário data de 9 de junho de 1959 e é a mais longa e cheia de expectativas. Encontram-se ali algumas observações metalinguísticas sobre a escrita autobiográfica e sobra a busca de si. Move-o o plano de ampliar o conhecimento de si e no entanto, no limite, avizinha-se da fratura mesma do sujeito: "Hoje tenho apenas o sol que entra pelo retângulo da janela. Que fazer com tanta luz? Nada, absolutamente nada. Não me pertence. Serve, quando muito, para pôr em evidência, por contraste, minha confusão interior (Fortes, 2012 , p.74). Seguirá, para devassar essas dificuldades, o seguinte preceito: "Vamos proceder calma e cautelosamente. Com método" (ibidem, p.74).

Salinas Fortes mudara-se do interior de São Paulo - Araraquara - para a sua capital com o objetivo de iniciar os seus estudos superiores. Os primeiros anos foram felizes: "Vivia muito bem neste universo, mais como espectador do que como ator. Sugava os livros como um vampiro e sua seiva transfusionava-se para dentro de mim, dando a impressão de que era a minha própria. Vivia feliz!” (ibidem, p.75). Essa harmonia haveria de romper-se adiante, mas nunca perderia o objetivo de colher em formas claras o conhecimento do mundo: "Antes de tudo, quero enxergar claro. Lucidez: eis a principal exigência" (ibidem, p.77). Há duas dificuldades nesse processo: a primeira diz respeito à busca rousseauniana de sinceridade, que examinamos anteriormente, e o sentido mesmo da escrita.

Suas frases demonstram senso de ritmo e delicadeza, como esta: "Todo passo abafado sobre fundo de silêncio noturno carrega uma certa malícia" (ibidem, p.80-1). Apresentam-se os objetos do quarto com descrição plástica, em uma combinação habilidosa de tempo de espera e imobilidade dos objetos, à semelhança de uma natureza morta de Cézanne: "Mais um pouco, mais um pedaço de tempo deverá ainda ser ocupado por estes óculos sobre a mesa, este maço de cigarros Continental e os livros mudos" (ibidem, p.81). A preocupação com a descrição pictórica também comparece em outra passagem, na qual se esforça por colher fenomenologicamente a imagem das coisas ao seu redor sob os efeitos do por do sol. Como se tudo se filtrasse na essencialidade do róseo: "O 
sol vai declinando lenta e fixamente. As coisas todas repousam espectralmente no róseo" (ibidem, p.93).

A entrada de 4 de julho de 1965 é especialmente importante: esclarece que o seu caderno permaneceu quase todo ele em branco - as páginas em branco são, a esse respeito, bastante significativas; o autor a escreveu um ano após o golpe militar e cinco anos após a última entrada no diário; manifesta a possibilidade de encontro do estilo próprio, um dos motivos presentes nessas anotações, mas parece desiludir-se de encontrar-se a si mesmo:

Já não me reconheço mais nas suas ingenuidades e na ignorância ignorante de si mesma que se acha estampada aí. Houve transformações, não há dúvida. Progresso? Mas há algo que permanece. Ganhei em lucidez, em amadurecimento. Meu domínio sobre os meios de expressão é hoje muito maior. Há, porém, um fundo permanente que não se abalou com todas as experiências acumuladas ao longo destes cinco anos. Se me libertei de muitos fantasmas, ainda não me libertei de mim mesmo. "On ne guérit pas de soi-même", diz Sartre - ainda Sartre - em Les Mots. (ibidem, p.84)

A desilusão destitui-se de conotação necessariamente negativa, e assume signo crítico no conhecimento de si e do mundo. De outro modo, poderia iludir-se com a apresentação de si como objeto que se decifraria se confiado ao método apropriado, operação evidentemente fadada a equívocos diversos quando referidas a um ser que timbra em temporalidade e precariedade. $\mathrm{O}$ diário deverá necessariamente fracassar, para que possa cumprir o seu destino.

\section{As tramas do silêncio, memória e testemunho}

Voltaremos ao paternalismo e à bondade. - Que felicidade! (Schwarz, 2014, p.115)

Muda-se o tempo da enunciação para o presente em diversos momentos do texto. Esse recurso narrativo sublinha a persistência dos eventos passados na memória do autor, compondo o liame necessário entre eles. Tomem-se esses exemplos, nos quais memória e testemunho sobressaem. O primeiro relembra o caráter sombrio dos eventos: "Hoje, muitos anos passados, continuo achando tudo muito sinistro, evidentemente. Mas que se há de fazer?" (Fortes, 2012, p.97). O segundo articula vida, morte e destino: "Se é verdade que a morte converte a vida em destino, a sensação de destino me converte agora a vida em morte. Muitos anos passados" (ibidem, p.98). O terceiro sublinha, nas margens da voz e da palavra, o silêncio dos desaparecidos: "Gostaria de passar a palavra aos outros companheiros, mas muitos deles já não têm voz" (ibidem, p.100). O último nota a persistência da dor: "Hoje, a paisagem é outra, mas as grades, ainda as trago comigo, plantadas duramente na memória” (ibidem, p.115).

A conclusão do livro não é tarefa fácil. Existem ainda muitas coisas e eventos que se devem arrancar ao esquecimento, e então lhes conceder a forma apropriada: "Mas, de delírio em delírio, fui me esquecendo de tanta coisa, como concluir? Não, um pouco mais de paciência, até que o exorcismo se complete e 
o vômito desengasgue. Tanta coisa esquecida..." (ibidem, p.101). Algumas páginas mais serão necessárias. Talvez até o momento em que se admita no fracasso da escrita a única forma de resposta apropriada a esses eventos traumáticos? Parece sinalizar a necessidade de o sujeito superar o sortilégio do passado, quando esse se imobiliza e se impõe como efígie indestrutível. Embora seja difícil, por força de resistências internas de teor e intensidade variadas, o sujeito deve mover esse passado de modo que torne a vida no presente outra vez possível, no sentido de aberta a novas modalidades de existir. No entrelaçamento entre memória, esquecimento e dor, o autor cuida em não perder-se na mera coleção de fatos. Observem-se essas frases, com a sequência de verbos em staccato e gradação, que oferece a imagem concisa do que se tentou testemunhar no livro: "Mas como esquecer? O meu tempo livre, agora, na nova vida das ruas estrangeiras, mas familiares, fazendo-me deslembrar um pouco dos fantasmas polimorfos, que de novo voltam a me afetar, delimitar, despedaçar, corroer, doer" (ibidem, p.102).

É uma escrita que mobiliza diversos recursos estilísticos e narrativos. Também recorre a gêneros variados, como o epistolário. Encontra-se aí uma longa carta, sem destinatário explícito. Lugar e data são informados: Paris, outubro de 1977. É notável pelas alusões a importantes acontecimentos políticos que decorriam naquele momento. Faz algumas considerações iniciais sobre o filme O fundo do ar é vermelho, de Chris Merker: "Apesar do ceticismo e do torpor em que nos submerge nossa década de poluição universal, Marker consegue nos mostrar com uma intensidade inesperada que o fundo do ar ainda anda banhado em uma tonalidade vermelha" (ibidem, p.102). É duvidoso que esse documentário deixasse entrever a persistência da utopia. Parece inclinar mais ao pessimismo de quem vê o fervor revolucionário da época recuar ao pano de fundo, afastando-se, ao menos em curto prazo, do proscênio da história. De todo modo, nele haveria decerto lições encorajadoras, apesar do tom aparentemente pessimista do filme: "A certeza, trazida pelo desfecho da guerra do Vietnã, de que o imperialismo pode ser vencido e, em segundo lugar, de que a luta continua, ressurgindo o inimigo sob novas e mais sofisticadas roupagens" (ibidem, p.105).

A pluralidade de estilos responde assim com a sua riqueza de estratos narrativos à interdição do diálogo que o autor testemunha. Assombram por vezes os seus sonhos a lembrança das prisões: "Na noite passada, sonho de prisão. Outra vez" (ibidem, p.115). Elucida em frase sob a forma de um oximoro aparente o sentido mais amplo desses sonhos: "Uma característica do sonho é seu grande realismo" (ibidem, p.116). Nesse plano de inversões que experimenta não é o sonho, mas o real mesmo quem assume a forma de um delírio: "Mas, antes, é preciso tomar consciência do real. Aceitar calmamente este real que parece um delírio circular, ele também" (ibidem, p.117).

A história comparece assim com as cores de um evento semelhante a um sonho coletivo. Traça a esse respeito um paralelo sugestivo entre as mensagens 
que lê em um muro - em uma delas estava escrito "Viva Bakunin!" - e as suas próprias páginas. Ambos os materiais são rastros e sinais dos sonhos e desilusões de determinados grupos sociais: "Aqui no meu muro-alvo, imitando o mestre, as confissões. Tramadas no inferno e recapturadas à luz das ruas ensolaradas, vestidas de cor e o corpo completo sonhado, não mutilado. Como permanecer fiel à utopia?" (ibidem, p.118). Divisa-se nessas frases a resistência a imergir meramente na exploração da subjetividade. Mesmo a confissão das suas dores guardam a visada no conjunto mais amplo da história do país, com as dúvidas de que ainda se faça justiça perante todo o descalabro que modificou a vida de tantas pessoas. Marilena Chauí (2012, p.14) sublinha esse enlace de tragédia pessoal e coletiva presentes no livro: "somos levados a ver o traçado de uma experiência impossível: a vertigem lúcida. Esforço para compreender uma tragédia pessoal e coletiva, fazendo-a memória e medida de um tempo fugidio que poderia cair no esquecimento". O quadro timbrava em elementos surreais - mistura de princípios éticos, referidos à defesa da pátria e das instituições nacionais, de que despontava a família brasileira, e a tortura em nome desses mesmos ideais cavalheirescos. O bem exigia estranha sorte de sacrifício, nessa mistura mal formada de discurso normativo e decisões pragmáticas.

No desfecho do livro, Salinas Fortes faz uma análise lúcida do contexto político que transitaria do golpe a uma redemocratização futura que se lhe afigurava destinada ao controle das elites locais e estadunidenses. Por essa razão, à memória subjetiva se referia a questão política mais ampla: "E tudo ficará na mesma? Os mesmos senhores de sempre continuarão tranquilos, comandando como se nada tivesse acontecido?" (Fortes, 2012, p.120). O delineamento desse problema ainda é difuso e assombrado pela revivescência das formas autoritárias que surpreendem o cotidiano do país. Não lhe escapa a reflexão acerca das dificuldades da transparência no exercício da escrita, seja pela opacidade da linguagem, seja pela visada nas contradições do próprio estatuto do sujeito no mundo moderno. As escolhas metodológicas e narrativas consistiram na convergência do testemunho pessoal e da denúncia coletiva, cuidando para que as necessidades de expressão íntima nunca se fizessem às expensas da atenção concedida aos silêncios da pólis.

\section{Notas}

l A palavra Urszene, no original, pode ser traduzida por "cena primitiva" ou "cena primária”.

2 A esse problema a autora dedicou todo um livro, a partir do projeto benjaminiano Rousseau-Gide, sobre o declínio da sinceridade (Damião, 2006).

3 Bento Prado Jr. (1988, p.7) sugere tratar-se igualmente de uma experiência catártica: A catarse esperada pela escrita das suas memórias: "essa purgação ou catarse do terror do tempo passado". 
4 Essa formulação de Marx encontra-se no Livro I do Capital, na seção dedicada ao exame do fetichismo da mercadoria: "Eles não sabem disso, mas o fazem" (Marx, 2013, p.149). Para uma discussão instigante sobre as relações entre cinismo e ideologia, consultar Eles não sabem o que fazem, de Slavoj Zizek (1990, p.59s.), especialmente o diálogo que estabelece com Peter Sloterdijk.

5 A expressão “Gênio maligno" refere-se à hipótese apresentada por Descartes na obra Meditações. Insere-se no âmbito do exame dos resultados da dúvida hiperbólica com a qual esperava encontrar bases sólidas para a construção do conhecimento.

\section{Referências}

ADORNO, T. W. Teoria estética. Trad. Artur Morão. São Paulo: Martins Fontes, 1982. CANDIDO, A. Posfácio. In: FORTES, L. R. S. Retrato calado. São Paulo: Cosac Naify, 2012.

CARDOSO, I. Os silêncios da narrativa. Tempo social, São Paulo, v.10, n.1, p.9-17, 1998.

CHAUÍ, M. Apresentação. In: FORTES, L. R. S. Retrato calado. São Paulo: Cosac Naify, 2012.

DAMIÃO, C. M. Sobre o declinio da "sinceridade": filosofia e autobiografia de Jean-Jacques Rousseau a Walter Benjamin. São Paulo: Loyola, 2006.

A reconfiguração do conceito de sinceridade em teorias pós-modernas. Revista Ideação, Feira de Santana, n.31, p.15-38, jan./jun. 2015.

ECO, U. O nome da rosa. Trad. Aurora F. Bernardini e Homero E. de Andrade. Rio de Janeiro: Record, 1986.

FORTES, L. R, S. Retrato calado. São Paulo: Cosac Naify, 2012.

FREUD, S. História de uma neurose infantil (O homem dos lobos). In: Obras completas: v. 14. Trad. Paulo César de Souza. São Paulo: Cia. das Letras, 2010.

GAGNEBIN, J. M. Lembrar escrever esquecer. São Paulo: Ed. 34, 2006.

LEVI, P. É isto um homem? Trad. Luigi Del Re. Rio de Janeiro: Rocco, 1988.

MARX, K. O capital: crítica da economia política. Livro I: o processo de produção do capital. Trad. Rubens Enderle. São Paulo: Boitempo, 2013.

NERUDA, P. O canto geral. Trad. Paulo Mendes Campos. Rio de Janeiro: Record, 1996.

PRADO JUNIOR, B. Luiz Roberto Salinas Fortes (1937-1987). Discurso, São Paulo, n.17, p.7-8, 1988 .

QUARTIM DE MORAES, J. Resenha de Retrato calado, de Luiz Roberto Salinas Fortes. Lua Nova, São Paulo, n.15, p.150-3, out. 1988.

QUASIMODO, S. Poesias. Trad. Geraldo Holanda Cavalcanti. Rio de Janeiro: Record, 1999.

ROUSSEAU, J.-J. As confissões. Trad. Fernando Lopes Graça. 2.ed. Lisboa: Portugália Editora, 1964. 
ROUSSEAU, J.-J. Os devaneios do caminhante solitário. Trad. Fúlvia Maria Luiza Moretto. 2.ed. Brasília: Editora UnB; São Paulo: Hucitec, 1986.

SCHWARZ, R. A lata de lixo da história: chanchada política. 2.ed. rev. e ampl. São Paulo: Cia. das Letras, 2014.

WEINRICH, H. Lete: arte e crítica do esquecimento. Trad. Lya Luft. Rio de Janeiro: Civilização Brasileira, 2001.

ZIZEK, S. Eles não sabem o que fazem: o sublime objeto da ideologia. Trad. Vera Ribeiro. Rio de Janeiro: Jorge Zahar, 1990.

RESUMO - A narrativa de memórias pode ser o espaço de articulação entre as vivências do sujeito e o movimento da coletividade. Os dois níveis se sobrepõem especialmente no relato pessoal de eventos históricos traumáticos. A escrita assumiria nesse caso a função de cena substitutiva da pólis. É o caso do livro Retrato calado, de Luiz Roberto Salinas Fortes. Nessa obra sobressaem a articulação de elementos autobiográficos, busca e desencontro de si e testemunho das prisões que enfrentou por motivos políticos durante a ditadura militar brasileira. A tortura física e psicológica que sofreu projeta as suas sombras em todas as páginas, de que resulta a impossibilidade de uma escrita confessional completa e bem-sucedida, seja no plano autobiográfico, seja no político.

PALAVRAS-CHAVE: Memória, Silêncio, Testemunho, Tortura, Ditadura.

ABSTRACT - Memorial narratives may be the locus of articulation of a subject's experiences and collective movement. These two levels overlap, particularly in personal reports of traumatic historical events. Writing would assume in such cases the function of a substitutive scene of the polis. This is the case of the book Retrato calado (The silent picture), by Luiz Roberto Salinas Fortes. This work highlights the articulation of autobiographical elements, the subject's pursuits and mistakes, and the testimony his imprisonment for political reasons during the military dictatorship in Brazil. The physical and psychological tortures he suffered project their shadows onto the pages, resulting in the impossibility of a complete and successful confessional text, whether in the autobiographical or political sphere.

KErWORDS: Memory, Silence, Testimony, Torture, Dictatorship.

Gilmário Guerreiro da Costa é doutor em Teoria Literária pela Universidade de Brasília; pós-doutor em Literatura Comparada pela Universidade de Coimbra; pós-doutor em Filosofia pela Universidade de Brasília. @ - gilmario.filosofia@gmail.com / https://orcid.org/0000-0002-0307-0798

I Universidade de Brasília, Brasília, Distrito Federal, Brasil.

Recebido em 7.3.2018 e aceito em 25.5.2018. 
